\title{
La Habana Bourbônica. Reforma ilustrada e escravidão em Havana (1763-1790)*
}

\author{
por \\ Ynaê Lopes dos Santos ${ }^{1}$ \\ $\mathrm{CPDOC} / \mathrm{FGV}$
}

A eminência do Tratado de Paris (1763) coroou uma série de modificações na configuração do Mundo Atlântico. A Guerra dos Sete Anos havia anunciado a proeminência de novas potências do Velho Continente, alertando para a fragilidade do desenho das possessões europeias na América. Transformações urbanas pautadas nos princípios ilustrados foram ferramentas utilizadas pela Coroa espanhola, ao mesmo tempo em que a elite criolla de Cuba ansiava por mais escravos. O objetivo deste artigo é analisar como as reformas bourbônicas e o aumento da escravidão urbana foram orquestradas na cidade de Havana entre 1763 e 1790 .

PalavRas-ChaVe: Havana; reforma ilustrada; escravidão; espaço urbano; 1763-1790.

Cómo citar este artículo / Citation: Lopes dos Santos, Ynaê, "La Habana Bourbônica. Reforma ilustrada e escravidão em Havana (1763-1790)", Revista de Indias, LXXVII/269 (Madrid, 2017): 81-113, doi:10.3989/revindias.2017.003.

* O presente artigo é parte do primeiro capítulo da tese de doutorado defendida no Programa de Pós-Graduação em História Social da Universidade de São Paulo (USP) em setembro de 2012 com o financiamento da Fundação de Amparo à Pesquisa do Estado de São Paulo (FAPESP). Ver Santos, 2012.

1 Mestre e Doutora em História Social pela FFLCH-USP, atualmente é pesquisadora bolsista da Escola de Ciências Socias-CPDOC/FGV. Contato: ynaels@hotmail.com ynae. santos@fgv.br/55 21 981099487. ORCID iD: http://orcid.org/0000-0002-9685-9041. 


\section{A RETOMADA}

Em 19 de outubro de 1762, Ricardo Wall ${ }^{2}$-Secretário de Estado e do Despacho da Guerra da Espanha- recebeu um ofício baseado no testemunho de um comerciante espanhol que havia deixado a Grã-Bretanha há poucos dias. Na realidade, esse homem (cujo nome não foi revelado) havia sido apresado pelos ingleses quatro meses antes, quando saía de Buenos Aires; depois de passar mais de setenta dias em solo inglês, retornou para a Espanha confirmando o que já era sabido pelas autoridades: Havana havia capitulado3 ${ }^{3}$.

Três dias depois, o mesmo secretário recebeu outro ofício sobre a situação da cidade. Desta vez, as informações haviam sido conseguidas com o oficial da Marinha espanhola, Don Manuel Barcazan, que fora feito refém dos ingleses (junto com sua tripulação) durante uma travessia atlântica. No período em que ficou preso, Barcazan obteve dados detalhados sobre a invasão de Havana. Segundo o oficial, no dia 22 de junho, os ingleses conquistaram El Morro (uma das principais fortificações da cidade) por meio da ação conjunta entre um bombardeio naval e um ataque terrestre. Uma semana depois, eles conseguiram tomar a Plaza Mayor e todos os navios que estavam no porto. Ao que tudo indica, os colonos ainda ofereceram resistência por mais 10 dias, mas com pouca possibilidade de vitória - pois, além da superioridade bélica, os ingleses haviam dominado a Zanja, principal fonte de água potável da cidade. Sem escolha, os habitantes de Havana se renderam no dia 12 de agosto de $1762^{4}$.

O feito dos britânicos não passou despercebido dentre aquele que o testemunharam, muito menos dentre aqueles que, anos mais tarde, estudaram o assunto. Os arquivos espanhóis estão repletos de documentos que narram a tomada de Havana, bem como as inúmeras formas de resistência de seus habitantes. Há tempos que a historiografia lança luz sobre o tema sublinhando não só os eventos que marcaram a tomada da cidade, mas também as consequências dessa investida no devir da história de Havana ${ }^{5}$. Mais recentemente, Gustavo Placer e Elena Schneider pontuaram que os britânicos tinham muitos motivos para comemorar a conquista, sobretudo porque a tomada de

2 Cf. Kuethe, 1986. Archivo Historico Nacional, Madrid (AHN), Autógrafo de Ricardo Wall, Diversos-Colecciones, leg. 4, n. ${ }^{\circ}$ 281, 1777.

3 Tropas de la Habana. Guerra con Inglaterra, 1762, Archivo General de Simancas, Valladolid (AGS), Secretaria de Estado y del Despacho de Guerra, SGU, leg. 7302, n. ${ }^{\circ} 7$.

4 Idem.

5 Ver Pezuela, 1962: 22-23. Valdés, 1962: 55. Calleja Leal y O’Donnell Duque de Estrada, 1999. 


\section{Mapa 1. Vista de Havana em 1762}

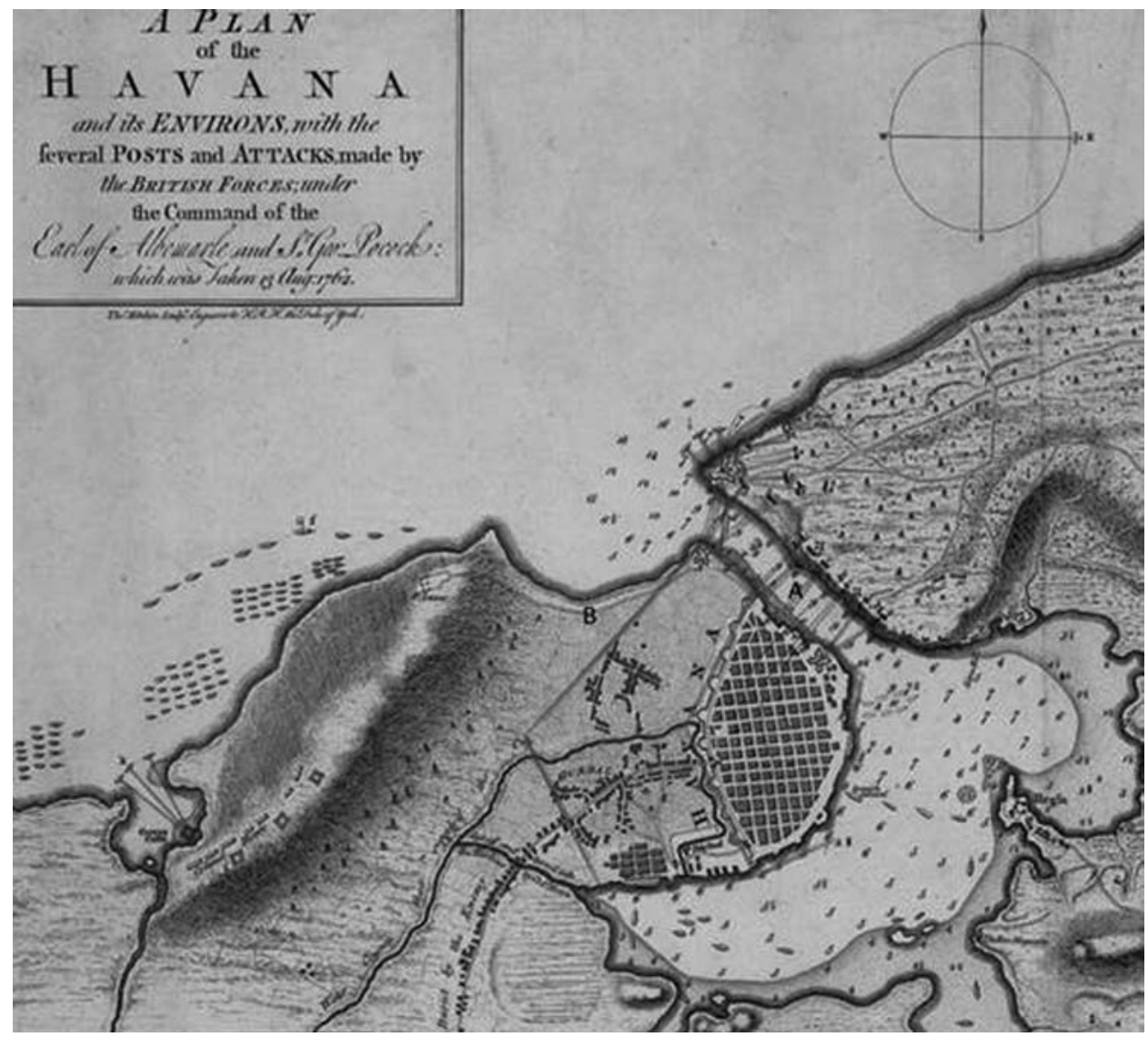

(Elias Durnford, A View of the City of the Havana, taken from the Road near Colonel Howe's Battery,1765). O plano de Havana desenhado pelo oficial inglês em 1762 aponta não só o detalhado conhecimento que as autoridades britânicas detinham da geografia de Havana e seus arredores, como indica que a marinha e o exército do rei Jorge III fizeram uso deste conhecimento para atacar a cidade. Tal plano ainda permite observar a estratégica posição de Havana (cujo porto principal era naturalmente protegido), bem como visualizar a sua porção amuralhada (em vermelho, letra A) e aquela que se localizava extramuros (em azul, letra B). Plano disponível no site: http://search.babylon.com.

Havana selava uma série de vitórias impetradas por eles durante a Guerra dos Sete Anos (1756-1763) .

6 Garcia del Pino, 2002. Placer, 2003; 2007. Schneider, 2011. 
Considerada como o primeiro conflito de dimensões mundiais, tal guerra pode ser entendida como um momento chave na disputa pela primazia global entre ingleses e franceses que, desde o início do século XVIII, estavam expandindo suas possessões nas Américas em um quadro de rivalidade crescente, que andava "pari passu" com a competitividade do comércio realizado nos oceanos Atlântico e Pacífico. A Espanha manteve-se neutra no conflito até 1759, quando Carlos III assumiu o trono. Membro da dinastia bourbônica, o novo soberano espanhol renovou o Pacto de Família (1761), oferecendo apoio ao também Bourbon Luís XV, rei da França. O governo britânico não viu essa aliança com bons olhos, e em janeiro de 1762, declarou guerra à Espanha ${ }^{7}$. A superioridade da marinha inglesa e o apoio que o exército de Jorge III recebeu dos colonos norte-americanos resultaram na ampliação do território britânico na América do Norte, na conquista de parte das Antilhas francesas e das cidades de Havana e de Manila (localizada nas Filipinas).

O Tratado de Paris (1763), assinado por representantes da França, Espanha, Grã-Bretanha e Portugal -ratificava o triunfo inglês na Guerra dos Sete Anos, ao mesmo tempo em que reorganizava as possessões no Novo Mundo com o intuito de satisfazer as potências envolvidas. A França abriu mão de suas terras no Canadá, mas voltou a controlar Guadalupe e Martinica (medida que também contemplava os interesses dos colonos britânicos). Como a expulsão francesa dos territórios do norte da América fazia parte do acordo, Luís XV abdicou do governo da Louisiana em favor da Espanha, sua aliada durante a guerra. Por fim, Carlos III cedeu a Flórida para os ingleses em troca de Havana ${ }^{8}$.

No ano de 1763, Havana voltava para o domínio espanhol. No entanto, como finamente trabalhado por Elena Schneider em sua tese de doutorado -já mencionada-, a presença britânica em Havana deixou sequelas que marcaram o devir da capital cubana9. Durante as últimas três décadas do século XVIII, a história e, sobretudo, a configuração urbana da cidade passariam por transformações que só seriam comparáveis com as realizadas em meados da década de $1830^{10}$.

7 Ver: Stein and Stein, 2003.

8 Elliot, 2006: 294-295.

9 Schneider, 2011

10 Diversos estudos sobre a história de Havana apontam que o período entre os anos de 1763 e 1792 foi de significativas mudanças urbanísticas na cidade. Cf. González-Ripoll, 2009: 253-272. 


\section{Havana: de pérola das Antilhas a laboratório da Ilustração}

Era com "muito gosto" que o recém-empossado Capitão General de Cuba, Conde de Ricla, contava de próprio punho as festividades em comemoração pela retirada dos ingleses, em junho de $1763^{11}$. A alegria que descrevera na carta endereçada à Sua Majestade parecia anunciar a esperança do Conde de Ricla em relação a seu futuro governo, que teria a árdua tarefa de reconstruir Havana -material e simbolicamente. Isso porque, a tomada da cidade pelos ingleses foi, a um só tempo, resultado da superioridade bélica dos britânicos e da incapacidade do exército espanhol em garantir a segurança de uma das possessões de seu Império. Parte do que foi considerado como "imperdoáveis erros cometidos pelos chefes militares durante as batalhas contra os ingleses"12 foi compilado pelos havaneiros ainda em 1762, e serviu como base para o inquérito aberto contra as lideranças militares que administravam Cuba na ocasião ${ }^{13}$.

Se não bastasse a narrativa da inaptidão das autoridades espanholas durante o combate ${ }^{14}$, Gustavo Placer e outros autores pontuaram que a covardia de muitos soldados peninsulares foi contraposta a atos de bravura protagonizados por sujeitos que, aparentemente, pouco tinham a ganhar arriscando suas vidas em nome do rei ${ }^{15}$. Santamaría y Vázquez Cienfuego sublinharam a medida tomada pelo governador de Cuba que, num ato de desespero, decretou liberdade aos escravos e índio fugidos e condenados que se encontravam nas fortificações da cidade, para que eles pudessem engrossar as frotas dos que defendiam a Coroa Espanhola ${ }^{16}$. Jane Landers narrou o caso heróico de um grupo de escravos que, por iniciativa própria e liderados por Gabriel Barba, pegou em armas para tentar impedir a entrada dos ingleses em Havana. Ainda que não tenham logrado êxito, a valentia inquestionável dos cativos acabou thes rendendo algumas condecorações, a ponto de Gabriel Barba receber uma medalha de ouro, ser alforriado e, assim, poder dar início a uma longa e respeitável trajetória militar no Batalhão de Pardos de Havana ${ }^{17}$. Seguindo parte da metodologia desenvolvida por Pedro Deschamps Chapeux,

11 Tropas de la Habana. Guerra con Inglaterra, 1763, AHN, Diversos-Colecciones, leg. 28, n. $^{\circ} 27$.

12 Guerra y Sanchéz, 1938: 166.

13 Cf. Kuethe, 1986: 20-23.

14 Vecinos de la Habana sobre las vejaciones por generales ingleses, 1762, Archivo General de Indias (AGI), Estado, leg. 7 , n. ${ }^{\circ} 9$.

15 Placer, 2003; 2007.

16 Santamaría y Vázquez Cienfuegos, 2013.

17 Landers, 2010: 138. 
Jane Landers e Gustavo Placer Cervera sublinharam a forte presença de escravos e homens livres de cor nas milícias de Havana e como esse "braço" armado foi fundamental na resistência à ofensiva inglesa em 1762, revelando assim interessantes vicissitudes da sociedade colonial escravista que, ao mesmo tempo em que permitia que escravos e seus descendentes forjassem outras concepções de identidade e de solidariedade por meio de uma inserção consentida pela administração espanhola, deixava claro que tal inserção seria feita dentro da forte hierarquia que organizava essa mesma sociedade colonial e escravista ${ }^{18}$.

À humilhação e revolta geradas pelo sucesso da invasão, somaram-se as benesses que a presença britânica representara na vida de boa parte dos habitantes da cidade. Até então, a única forma legal de comprar cativos oriundos do continente africano era por meio do asiento, sistema em que indivíduos ou companhias comerciais obtinham da Coroa o monopólio de venda de um número específico de escravos, com a contrapartida de pagar os impostos exigidos ${ }^{19}$. Os entraves fiscais acabavam tornando o preço de tais escravos muito alto, afastando pequenos e médios proprietários desse comércio. Se, durante a primeira metade do século XVIII, Havana chegou a ter mais de 30\% da sua população composta por cativos, isto se deveu em grande parte às aquisições da Coroa e ao avultado volume de contrabando que ocorria nos inúmeros portos naturais da ilha ${ }^{20}$. Os dez meses de domínio inglês haviam suspendido o monopólio exercido pela Coroa espanhola, permitindo que a elite havaneira experimentasse as vantagens do livre comércio e da surpreendente entrada -legalizada- de aproximadamente quatro mil africanos escravizados $^{21}$. A dominação inglesa não só abalou o sentimento de pertença dos havaneiros, como apresentou outro paradigma de relação comercial que passava ao largo dos ditames do mercantilismo monopolista ${ }^{22}$.

18 Deschamps y Pérez de La Riva, 1974. Placer, 2009. Landers, 2010.

19 De la Fuente, 2009: 129-151.

20 Idem. Importante salientar que em outras cidades de Cuba também havia uma forte demanda por escravos. Sobre Santiago de Cuba ver: Portuondo, 1996. Belmonte Postigo, 2007; 2010. Perera y Meriño, 2013.

21 Ver: Blackburn, 2003. Murray, 1980: 4. Marrero, 1984: 12. Tornero Tinajero, 1996: 35. Ainda que não leve em consideração o número de cativos que adentraram em Havana via contrabando, os números disponíveis no Voyages. The Trans-Atlantic Slave Trade Database http://www.slavevoyages.org, corroboram as últimas análises. Todavia, é importante ressaltar que a despeito da expressiva diferença entre os números apresentados, antes da invasão inglesa, o número de africanos escravizados que desembarcavam anualmente em Havana dificilmente ultrapassava 250 indivíduos. Cf. Aimes, 1907: 29.

22 Schneider, 2011. 
Ao mesmo tempo em que mostrava às autoridades espanholas que os tempos eram outros, a invasão britânica pareceu destacar o papel ímpar que Havana exercia no Mundo espanhol. Desde sua fundação, a localização geográfica foi um aspecto fundamental na trajetória da cidade. De acordo com Moreno Fraginals, Havana parecia "ter sido posta no lugar preciso, na encruzilhada exata do caminho marítimo de volta à Europa"23. Criada em 1515, na região sudeste da ilha de Cuba, San Cristóval de La Habana se transformou, ainda no século XVI, num importante ponto de ligação entre diferentes partes do Império espanhol. A partir de 1570 -quando foi instaurado o sistema de frotas (também conhecido como Carrera de Indias)-, Havana tornou-se ainda mais importante economicamente e, em 1589, foi elevada ao status de capital da capitania de Cuba. A partir de então, Havana passou a ser um dos maiores e mais expressivos entrepostos do império, já que era o primeiro ponto de chegada de todos os navios que saíam da Espanha, e o último porto das embarcações que deixavam a América hispânica em direção ao Velho Continente. A construção de um estaleiro que produzia navios de guerra, bem como o cultivo de tabaco e a criação de gado ampliaram ainda mais a economia havaneira, permitindo, assim, a criação de verdadeiras fortunas na cidade e seus arrabaldes ${ }^{24}$.

Essa pluralidade agrária repercutiu na dinâmica urbana de Havana, desenvolvendo uma gama diversificada de atividades artesanais que não estava diretamente atrelada à produção ou escoamento dos produtos cultivados na hinterland. Um dos exemplos mais emblemáticos eram os esclavos tabacaleros, ou seja, os cativos que processavam as folhas de tabaco produzindo os charutos, fomentando uma indústria fundamentalmente urbana. Vale ressaltar que o tabaco foi um importante gênero para a economia cubana. Reforçando a tese de Fernando Ortiz, Casanovas apontou que durante os primeiros anos do século XVIII, a indústria do tabaco (cultivo da folha, manufatura dos charutos e exportação do produto) foi responsável pelo crescimento da população de Havana e pelo uso de boa parte dos escravos urbanos. Numa linha muito próxima, Vicente Sanz demonstrou como a produção do tabaco foi fundamental para que parte da oligarquia senhorial de Cuba lutasse pela maior oferta de escravos na ilha ${ }^{25}$. Junto com o cultivo e o manuseio do tabaco e o artesanato, a Havana do século XVII também foi marcada pelo incremento das

23 Moreno Fraginals, 1995.

24 Sobre os primeiros anos da história de Havana conferir: Arrate y Acosta, 1964. Roig de Leuchsering, 1963. De la Fuente, 2008.

25 Sobre a produção de tabaco em Cuba ver o estudo basilar de Ortiz, 1947: 103-253. Estudos mais recentes sobre o tema são; Casanovas, 1998: 15-42. Sanz Rozalén, 2009. 
camadas médias da sociedade -formada por criollos menos abastados, migrantes europeus e negros forros-, bem como pela ampliação do perímetro urbano, a construção de edifícios grandiosos e o aumento significativo de igrejas e construções eclesiásticas (como conventos e monastérios).

Ainda que o boom do açúcar produzido em Cuba ocorresse somente após a Revolução do Haiti (1791-1804) -que resultou no colapso da economia de Saint-Domingue- recentemente, os trabalhos de Mercedes García Rodríguez apontam que desde o início do século XVIII, a oligarquia de Havana estava empenhada em produzir açúcar nas hinterlândia de Havana não só por meio da solicitação do aumento da oferta de escravos na ilha, mas também apostando, desde cedo, na modernização do processo de fabrico do açúcar ${ }^{26}$. Em nome da produção do tabaco e do açúcar, a oligarquia de Havana clamava por mais braços escravos que também seriam alocados em outras atividades da dinâmica vida urbana da capital de Cuba. Observa-se então que em meados do século XVIII, e a despeito da baixa oferta de escravos, Havana já tinha uma economia diversificada e dinâmica, com produtos de diferentes regiões do mundo e, justamente por isso, tornou-se um dos pontos mais cobiçados por nações estrangeiras.

Embora contenham abordagens e perspectivas distintas, é possível afirmar que a maior parte dos estudos que se debruçaram sobre o período, como os trabalhos de Elliot, Allan Kuethe, Sherry Johnson, Gustavo Placer, Elena Schneider e Mercedes García, concordam em afirmar que o poder metropolitano precisou organizar sua administração em duas frentes: por um lado, retomar o domínio efetivo daquela que foi reconhecida como a Llave del Nuevo Mundo, criando condições materiais e militares que impedissem novas invasões ${ }^{27}$. Por outro, exercer o controle da cidade, sem deixar de ampliar o diálogo com a elite havaneira que, embora fiéis aos Bourbons, soube utilizar a experiência do domínio britânico para elaborar sua plataforma de reinvindicação: a elite criolla ansiava por maior liberdade comercial e por mais braços escravos ${ }^{28}$.

Valendo-se da experiência militar e administrativa no império hispânico o catalão Ambrosio de Funes Villalpando Abarca de Bolea, Conde de Ricla, propôs uma reorientação radical da estratégia de defesa da ilha, que envolvia a polêmica criação de três regimentos de milícia -com três batalhões cada-

26 García Rodríguez, 2000; 2004; 2007.

27 Elliot, 2006. Kuethe, 1986: 24-49. Johnson, 1997. Placer, 2009. Schneider, 2011. Kuethe y Andrien, 2014. 2006.

${ }_{28}$ No caso específico de Havana no íncio do século XVIII, ver: García Rodríguez, 1994; 
compostos por colonos ${ }^{29}$. Durante dois meses, Carlos III e seus principais ministros estudaram a proposta de Ricla, pontuando os possíveis riscos gerados pela educação militar dos criollos $^{30}$. No entanto, a belicosidade que marcava o contexto Atlântico deixou a Coroa espanhola sem alternativas, recolocava a questão em outros termos: como viabilizar, economicamente, a criação desse braço do exército sem onerar os cofres públicos.

Os ideais ilustrados que pautaram o governo bourbônico desde o início do século XVIII balizaram a decisão final da $\operatorname{Coroa}^{31}$. Com a ajuda do marquês de Esquilache, Carlos III aceitou a proposta de Ricla, com a contrapartida de que a reformulação do exército espanhol em Cuba fosse acompanhada por mudanças fiscais que demandassem dos próprios criollos o financiamento da militarização colonial. Observa-se, então, que a necessidade de reestruturar a cidade foi encarada como uma boa oportunidade para colocar em prática, no Novo Mundo, os ideais de administração ilustrada que já organizavam diversos âmbitos da administração colonial ${ }^{32}$. Havana acabou tornando-se uma espécie de laboratório na implementação da política bourbônica nas Américas $^{33}$.

O aceite da proposta do Conde de Ricla veio junto com sua nomeação para Governador e Capitão General de Cuba. A ideia era que ele, pessoalmente, levasse a cabo o projeto elaborado meses antes. Ainda que não lhe faltasse as prerrogativas para ocupar o cargo, Ricla contou com o apoio fundamental do marechal Alejandro O'Reilly -futuro Capitão General de Louisiana ${ }^{34}$. A antiga amizade entre os dois impediu possíveis disputas de poder, favorecendo assim a boa execução do projeto. Como apontado por Allan Kuethe, enquanto o Conde de Ricla ficou responsável por restaurar a administração da ilha -supervisionando a reconstrução das fortificações e o desenvolvimen-

29 A experiência da Guerra dos Sete Anos havia descortinado a fragilidade das corporações militares no continente americano. Justamente por isso, a partir da década de 1760 , tanto a Inglaterra como a Espanha iniciaram uma forte política de ampliação e treinamento das milícias no Novo Mundo. Cf. Kuethe, 1986: 25-30. Elliot. 2006. Venegas Fornias, 2002: 38. Placer, 2009.

30 Kuethe, 1986: 28.

31 Kuethe, 1986. Naranjo Orovio y Santamaría García, 2002.

32 Idem.

33 Diversos trabalhos afirmam que a reconstrução de Havana após a invasão inglesa serviu como importante experiência para o governo ilustrado de Carlos III, experiência essa que pautou as ações da metrópole em outras localidades da América hispânica sem, todavia, lograr o mesmo sucesso. Ver: Elliot, 2006: 298-310. Kuethe, 1986: 24-49. Placer, 2009. Schneider, 2011. Kuethe y Andrien, 2014.

34 Kuethe, 1986: 30-32. 
to dos meios financeiros que garantiriam a expansão militar-, O'Reilly ficou livre para cuidar, especificamente, da conformação das tropas criollas $^{35}$.

Atendendo às necessidades criadas pela própria reforma militar e pela elite havaneira, Ricla utilizou seu poder e rompeu alguns entraves que existiam para a importação de gêneros básicos como a farinha, permitindo que os colonos negociassem diretamente com comerciantes estrangeiros (sobretudo com norte-americanos e ingleses), o que, por sua vez, facilitou a entrada de mais alimentos e escravos ${ }^{36}$. Afiançada pelo rei, a medida tomada pelo Conde de Ricla em 1764 foi ampliada no ano seguinte, quando Carlos III aboliu o monopólio da Companhia Real del Comercio de la Habana com os portos de Cádis e Sevilha. Em semelhança ao sistema de livre comércio imperial britânico, a Coroa hispânica viabilizou certa dinamização da economia havaneira permitindo a comercialização dos seus produtos com nove portos espanhóis.

\section{Antigos usos e as mesmas reinvindicações de uma cidade escravista}

A rapidez com a qual o Conde de Ricla e o Marechal O'Reilly reergueram Havana foi possível graças ao emprego de centenas de prisioneiros de guerra, homens livres e, principalmente, escravos. Para garantir que não houvesse falta de trabalhadores, o Capitão General conseguiu autorização real para a entrada de milhares de africanos escravizados na ilha ${ }^{37}$. Parecia que o Conde de Ricla havia ouvido as súplicas da elite cubana. Há muito que os vecinos de Cuba solicitavam mais cativos. Em 22 de março de 1752, por exemplo, o Secretário Sebastian Eslava recebeu um ofício no qual os criollos pediam que

Sua Majestade se digne facilitarles algun modo de proverse de Negros. Y pelo que mira a estos solos Pretendientes, se verifica del todo que su carestía marca de no tener donde comprarlos; pues alegan, no haver podido tomarlos de la Companhia de la Habana que se los vendia mitad a dinero decontado, y mitad a frutos de la cosecha, por no hallerse con lo primero ${ }^{38}$.

35 Ibidem: 33. Placer, 2009.

36 Guerra y Sanchéz, 1938: 171. Kuethe, 1986: 66-71.

37 Segundo as informações obtidas The Trans-Atlantic Slave Trade Database, aproximadamente 3.300 africanos desembarcaram em Cuba durante o governo do Conde de Ricla. Cf. http://www.slavevoyages.org.

Ao analisar as reconstruções feitas em Havana logo após a expulsão inglesa, Levi Marrero afirmou que sob a autorização de Ricla inúmeros africanos foram adquiridos, sendo que a Coroa espanhola comprou quatro mil cativos que foram alocados nas obras de fortificação. Cf. Marrero, 1984: 3.

38 Comercio. Negros. Cuba, 1752, AGS, Secretaría del Despacho de Guerra, leg. 6799, n. ${ }^{\circ} 36$. 
Segundo os criollos que assinaram o documento, embora muitas localidades do Império hispânico não precisassem de escravos africanos, a economia do Cuba só teria a ganhar com isso, pois esses homens e mulheres vindos da Guiné formariam a mão-de-obra necessária para a produção agrícola, fosse de tabaco, fosse de cana. A necessidade por escravos era tamanha que os autores do documento não se fizeram de rogados: caso seu pedido não fosse atendido, se manteria aberto "un amplíssimo campo a el contrabando" 39 .

$\mathrm{O}$ contrabando a que os vecinos de Cuba se referiam há muito era conhecido pelas autoridades cubanas e peninsulares. E se o sistema de asiento -que até então era a única forma legal de introduzir africanos escravizados em Cuba- não dava conta de atender as demandas da elite agrária da ilha, também não seria por essa via que o Conde de Ricla obteria os escravos necessários para a reestruturação das fortificações de Havana. Em tese, a exceção feita durante o governo de Ricla tinha um único objetivo: viabilizar a execução do projeto ilustrado de reforma urbana em Havana ${ }^{40}$.

Em certa medida, a liberação do comércio de escravos entre os anos de 1763 e 1765 acabou reforçando a importância que Havana -mais do que a totalidade de Cuba - tinha dentro do mundo hispânico. Mesmo porque, conforme pontuado por Tornero Tinajero, o comércio de africanos escravizados não foi um evento isolado; ele acabou fomentando as negociações da ilha com outras nações, relações essas que não faziam parte do pacto colonial imposto pela Espanha ${ }^{41}$. Com o intuito de conter os excessos da colônia, os peninsulares criaram, em 1765, a Compañia Gaditana de Negros, sediada em Cádis; entretanto tal empresa não teve sucesso na sua tentativa de controlar a entrada de africanos escravizados na ilha. O significativo volume de produtos (incluindo os cativos) que passaram pela aduana de Havana durante o governo de Ricla reforçou a proeminência que a capital cubana tinha sobre sua hinterlândia -que ainda estava longe do modelo de exploração observado em outras localidades do Caribe. Se, entre os séculos XVI e XVIII, é possível afirmar que não existia o sistema de plantation na ilha, as diversas atividades econômicas de Havana fizeram com que "a ilha fosse a cidade"42.

\section{Ibidem: 5.}

40 Parte das aparentes contradições do uso que governos ilustrados fizeram da escravidão pode ser encontrada na obra: Davis, 2001: 435-491.

41 Tornero Tinajero, 1996: 45-75. No artigo que escreveu sobre Havana no século XVIII, Allan Kuethe também destacou as transações comerciais realizadas entre negociantes havaneiros e comerciantes de outras procedências, principalmente estadunidenses. Cf. Kuethe, 1991: 13-39.

42 Expressão cunhada por Alejandro de la Fuente no livro em que analisa a história de Havana nos século XVI e XVII, a frase resume o lugar crucial que a economia de Havana 
As atividades portuárias e toda a rede de serviços oferecidos por uma cidade-porto (hospedarias, tabernas e pequeno comércio) eram, em grande parte, executadas por escravos. Em 1680, o primeiro diocesano de Cuba produziu uma série de regulamentos sobre a escravidão, que revelam parte das implicações do cativeiro em Havana. Preocupado com a conduta cristã, o clérigo defendia a proibição de mulatas e negras (livres e escravas) saírem de suas casas para ganhar jornal depois de anoitecer, prática essa que, sem dúvida alguma, poderia acobertar a prostituição. O trânsito dessa "classe" de mulheres pelas vias e tabernas de Havana horrorizava o autor das posturas, que também se mostrava decepcionado com os senhores, já que eles permitiam que:

Las dichas esclavas jornaleras vivan fuera de sus casas, alquilándoselas en la ciudad a otras personas, sino que las recojan de noche en las suyas, para que debaxo de su mano y disciplina, vivan honestas y recogidamente, y se eviten los daños referidos; y ser las casas que alquilan dichas esclavas lugares publicos ${ }^{43}$.

Ao que tudo indica, algumas leis divinas não se aplicavam ao cotidiano escravista, e boa parte das mulheres de cor -escravizadas ou não- continuou ganhando seu sustento nas ruas da cidade. Muitos bandos de gobierno (leis municipais) publicados ao longo do século XVIII apontam que a retidão católica esteve longe de pautar a dinâmica dos trabalhos exercidos pelos escravos citadinos. Assim como o código elaborado em 1680, tais documentos tentavam legislar sobre costumes decorrentes da maior autonomia desfrutada pelos cativos urbanos: possibilidade de morar sobre si, fugas e pequenos delitos cometidos por esses escravos foram pautas de alguns bandos publicados pelos Capitães Generais que governaram Havana. Todavia, a reincidência dos assuntos levantados pelas autoridades nos séculos XVII e XVIII demonstra que essas práticas continuaram recorrentes na capital cubana, corroborando a tese de que Havana era uma cidade escravista muito antes da implementação do sistema de plantation escravista em Cuba, e, nesse momento, a despeito dele 44 .

desfrutava dentro do Império espanhol no período examinado pelo autor. Cf. De la Fuente, 2009: 132-144.

43 "El Adecentamiento de la Iglesia en Cuba y la regulación de la esclavitud", libro I, título II, constitución X, 1680, en Torres-Cuevas, 1986: 28.

44 Estudos recentes que analisaram a história de Havana entre os séculos XVI e meados do século XVIII defendem a tese da proeminência da escravidão urbana nesse período. Cf.: Moreno Fraginals, 1995. García, 2003. De la Fuente, 2008. Barcia, 2009a. Até mesmo análises mais antigas, que entendiam a escravidão urbana como uma faceta menos importante do 
A própria existência de uma expressiva população de "homens de cor" livres e libertos, e a sociabilidade criada por eles eram fortes indícios da natureza da escravidão urbana de Havana. As atividades citadinas colocavam os escravos constantemente em contato com dinheiro, o que potencializava a compra da liberdade -fosse ou não por meio da coartação ${ }^{45}$. A trajetória dos cabildos de nação, confrarias e até mesmo dos batalhões de Pardos e Morenos (negros) Livres de Havana também apontam para as complexidades de uma sociedade que dependia em larga medida do trabalho escravo ${ }^{46}$. Essas complexidades foram, em parte, muito bem lidas pelo Conde de Ricla e pelo marechal Alejandro O'Reilly, que souberam usar uma das facetas identitárias desenvolvidas pelos membros dessas milícias de homens de cor. Todavia, como demonstrado por Ovídio Ortega Pereyra, o emprego de negros e mulatos livres nas milícias criou uma série de tensões para as autoridades cubanas, na medida em que tais homens, quando armados, poderiam converter-se em fortes ameaças para a manutenção da ordem de uma sociedade racializada e calcada no peso da escravidão ${ }^{47}$.

Dentro da lógica de uma cidade-porto que detinha um dos mais importantes estaleiros do mundo atlântico, não é de espantar que a maior senhora de escravos da cidade fosse a própria Coroa espanhola ${ }^{48}$. María Elena Díaz demonstrou em estudo centrado entre os anos de 1670 e 1780, que a compra de africanos escravizados pela Coroa, os esclavos del rey, era uma prática corrente na cidade desde o século XVII ${ }^{49}$. A necessidade constante em garantir o bom estado das fortificações, a construção de embarcações no Real Arsenal e, principalmente, a produção de tabaco, demandavam a compra dos escravos reais. Deste modo, as ações do Capitão General no tocante à liberalização temporária do tráfico podem ser compreendidas como o incremento de uma prática amplamente difundida: muitos africanos escravizados que entraram em Havana entre 1763 e 1765 tinham como destino final as atividades citadinas, Conforme bem sublinhado por Pablo Tornero Tinajero, a

escravismo de Cuba, indicam diversos documentos que permitem atestar o peso que a escravidão citadina tinha na capital cubana. Cf. Ortiz, 1987.

45 Ainda que seu recorte temporal seja o século XIX, em sua tese de doutorado Claudia Varella desenvolveu um interessante trabalho sobre o sistema de coartação em Havana, analisando as sutilezas dessa prática. Varella, 2010.

46 Barcia, 2009a.

47 Ortega Pereyra, 1998.

48 De la Fuente, 2009: 138. Na apresentação de seu livro, María del Carmen Barcia aponta que, assim como ocorria em diversas relações entre senhores e escravos, muitos cativos pertencentes a Coroa acabavam adotando del Rey como sobrenome. Barcia, 2009b: 18.

49 Díaz, 2012. 
Figura 1. Uniforme do batalhão de Negros de Havana, 1763

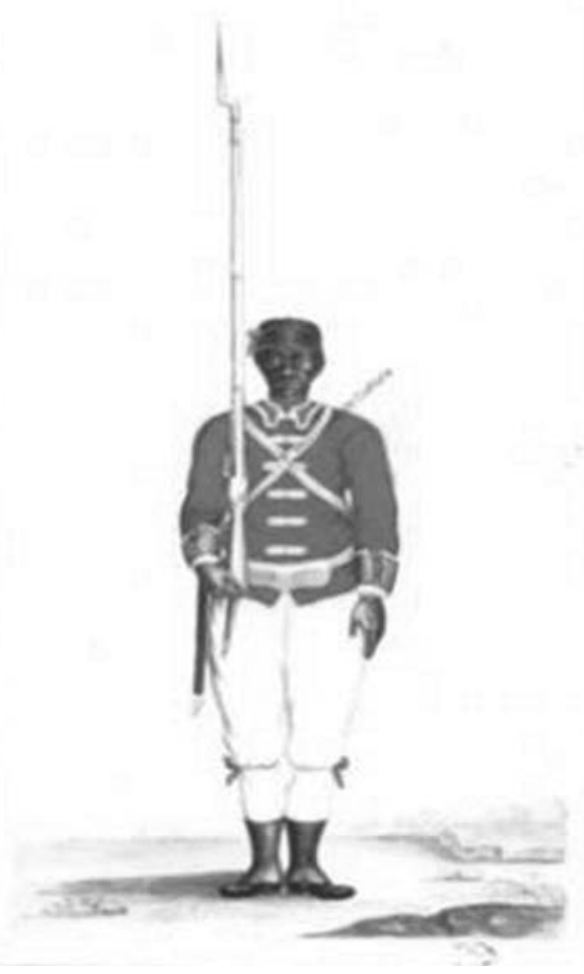

(Diseño de uniforme del Batallón de Morenos de la Habana. Mapas y Planos, 1763, Archivo General de Índias). Desde 1586, as autoridades espanholas utilizavam mulatos e negros livres na composição das tropas voluntárias em Cuba. Como apontado por diversos especialistas, a organização dessas tropas era reflexo da estrutura escravista da ilha, na medida em que a relação (direta ou indireta) com a escravidão criava uma série de diferenciações entre os batalhões de "homens de cor" e as demais milícias cubanas. Todavia, ainda dentro da lógica escravista, tais organizações foram fundamentais para a mobilidade social e criação de laços de solidarierade de muitos egressos do cativeiro, que fizeram da sua pertença ao exército espanhol um elemento de distinção econômica e status social, o que muitas vezes eram expresso pelas vestimentas utilizadas.

Coroa espanhola passou a afiançar o tráfico de escravos para suas possessões no Novo Mundo ${ }^{50}$.

50 Tornero Tinajero, 1996: 24. 
Como vem sendo pontuado, o Conde de Ricla buscou equacionar interesses metropolitanos e coloniais no que diz respeito à escravidão ${ }^{51}$. Ainda que a maioria dos africanos escravizados importados durante seu governo tenha sido comprada pela e para a Coroa, é inegável que essa entrada de escravos acabou facilitando o acesso legal dos havaneiros e ainda fomentou a economia local de Havana, na medida em que transformou a venda e o aluguel desses cativos numa atividade rentável para os futuros senhores. Exemplo disso, foram as reivindicações feitas nesse período pelos senhores de Santiago de Cuba que, como pontuado por Olga Portuondo e José Belmonte, mostravam-se ressentidos pela preferência dada às demandas da oligarquia havanei$\mathrm{ra}^{52}$. Todavia, a despeito das boas intenções de Ricla, a demanda por cativos continuava sendo uma das maiores reinvindicações dos criollos de Cuba.

$\mathrm{O}$ caso de Jossef Antonio parece ilustrar muito bem os múltiplos usos e limites da escravidão urbana naquele momento da história da cidade. Como consta em uma das diligências da Intendencia General de Hacienda de Cuba,

Um negro que diz ser escravo do Rei foi apreendido ontem pelo subtenente [...] e declara que há muitos anos fugiu das obras de Sua Majestade e que foi recolhido por Jacinto Tapia, morador do Partido de Guaydo, e que esteve em seu poder por doze anos na qualidade de escravo, até que foi vendido a Phelipe Tapia, seu irmão, e este a Antonio Quintana ${ }^{53}$.

As mudanças de senhor sofrido pelo escravo revelam facetas interessantes do uso de escravos na segunda metade do século XVIII em Havana. A leitura completa do documento permite compreender que o escravo do rei era Jossef, cativo que trabalhava na construção da fortaleza La Cabaña quando fugiu, em meados de 1765 . O fato em si não aponta nenhuma novidade relevante, tendo em vista que a fuga sempre foi uma das principais formas de resistência à escravidão nas Américas. O curioso deste caso foi que Jossef ficou pouco tempo foragido. No mesmo ano de 1765, ele foi apresado por Jacinto Tapia, morador da cidade. No entanto, ao contrário do que se poderia esperar de um leal súdito de Carlos III, de acordo com o testemunho dado pelo escravo, Tapia não devolveu Jossef para as autoridades. Sem muitos questionamentos morais, Jacinto Tapia outorgou-se senhor de Jossef, que ficou (ilegalmente) sob seu poder por doze anos. A fraude só foi descoberta em 1777, quando Jacinto, por intermédio de seu irmão Philipe, tentou vender

51 Schneider, 2011.

52 Portuondo, 1996. Belmonte Postigo, 2010.

53 Sem título, 1777, Archivo Nacional de Cuba, La Habana (ANC), Intendencia General de Hacienda, leg. 628, n. ${ }^{\circ} 20$. 
Jossef para José Antonio Quintana. Ao solicitar os documentos que atestassem a posse do escravo, Quintana percebeu a irregularidade, e foi atrás das autoridades competentes, que prenderam Jacinto e recolheram Jossef ${ }^{54}$.

Não é possível afirmar se foi oportunismo ou simples má-fé que levou Jacinto Tapia a apoderar-se de Jossef Antonio. O caso é que o longo período em que Jossef ficou em poder da família Tapia ilustra não só as dificuldades em se adquirir um escravo em Cuba na década de 1760, mas também sugere que o reconhecimento de um escravo foragido não era tarefa simples na Havana de então. Embora a Coroa tenha tomado atitudes que diferenciassem os trabalhos exercidos por escravos e libertos em Havana -a partir de 1763, as atividades aduaneiras (descarga e transporte de mercadorias) ficaram proibidas aos cativos, tornando-se trabalho exclusivo dos negros e mulatos livres ${ }^{55}$, uma cidade cujo percentual da população escrava girava em torno de $35 \%$, era um bom esconderijo para cativos foragidos, que ainda poderiam se confundir com os outros milhares de negros livres e libertos que ali viviam.

Como apontam muitos documentos localizados nos arquivos cubanos, a possibilidade da fuga dentro da própria cidade apenas reforça o argumento defendido por diversos autores (dentre os quais se destaca Alejandro de la Fuente), que a capital cubana já era escravista antes do boom açucareiro na ilha. Mesmo porque, como apontado pelo caso de Jossef, o anonimato desfrutado pela população negra nos grandes centros urbanos poderia, por vezes, beneficiar outros sujeitos que não os escravos foragidos. Se muitos cativos fizeram de Havana seu esconderijo, alguns senhores conseguiram se apropriar da precariedade e instabilidade que marcaram a fuga dentro das cidades para reescravizar cativos de terceiros, sem que isso chegasse ao conhecimento das autoridades.

No ano seguinte à descoberta da fraude da família Tapia, uma acusação muito semelhante chegou até Juan Ignacio Uriza, uma das principais autoridades de Cuba.

Na manhã de ontem, por voltas das nove horas, o Mestre das obras do Rei, Don. Andres de Olivares, me apresentou nas obras de San lazaro um negro que parecia boçal, dizendo que era de Sua Majestade destinado á construção do Caste-

54 Idem.

55 Segundo Deschamps Chapeaux, as atividades aduaneiras que, até 1763, eram executadas por escravos e libertos, passaram a ser exclusivamente feita por alforriados e livres. Um das razões para isso era assegurar que os homens que compunham os Batalhões de Pardos e Negros livres de Havana tivessem uma fonte de renda garantida, que não concorresse com o trabalho escravo. Cf. Deschamps Chapeaux y Pérez de La Riva, 1974: 17. 
llo de Atares e que estava, na realidade, em serviço do Capitão Nicolas de Nates, como se fosse sua propriedade ${ }^{56}$.

A acusação acima narrava um caso mais sério, pois envolvia diretamente importantes nomes de Havana. Andrés Olivares, mestre de obras do Rei, acusava o capitão Nicolau Nates de se apossar indevidamente de Félix, escravo que trabalhara nas obras reais desde o governo do Conde de Ricla. Segundo o testemunho de Olivares, que ocupou muitas páginas, essa não era a primeira vez que Nates apoderava-se de escravos reais para usufruto próprio ${ }^{57}$. Mas, comprovar a culpa de Nates não seria tarefa simples. Em primeiro lugar porque ele era, desde 1782, capitão da Milícia de San Lázaro e comandava três sargentos, quatro cavaleiros e trinta e um soldados ${ }^{58}$. Segundo, porque o escravo em questão havia morrido anos antes, o que faria do caso uma disputa de palavras. De acordo com o capitão, as injúrias do mestre de obras eram decorrência de um entrevero ocorrido anos antes, no qual Nates não teria pago alguns jornais para Olivares ${ }^{59}$. Como era de se esperar, a briga de forças acabou pendendo para o lado do capitão, que foi inocentado das acusações. Mas é possível que essa mesma "força" tenha servido para escamotear a situação irregular de um importante criollo de Havana que, assim como tantos outros, fez valer seu poder para ter acesso facilitado a um escravo.

A despeito dos interesses da elite agrária de Cuba e dos usos paralelos que eram feitos dos escravos urbanos, a maior parte dos cativos que foram trazidos para a cidade durante o governo do Ricla trabalharam sob as ordens de um governo que não poderia deixar que Havana caísse novamente em mãos inimigas. A partir do momento em que a segurança da capital de Cuba estava minimamente garantida, as autoridades espanholas intensificaram o processo de (re)conhecimento e mando da cidade -incluindo o maior controle sobre seus habitantes, sua região intra e extramuros e suas zonas rurais. Fazendo uso da estrutura eclesiástica já existente, o Capitão General Antonio María de Bucareli y Ursúa (1766-1771) criou mais subdivisões em Havana que, por sua vez, passaram a ser administradas por órgãos específicos. Os assuntos relativos aos bairros urbanos continuavam sob o comando do cabildo ${ }^{60}$, que a partir de então designava comissários de bairro responsáveis por inscrever os habitantes, vigiar meliantes, controlar os movimentos e traslados, e também

\footnotetext{
56 Sem título, 1778, ANC, Intendecia General de Hacienda, leg. 494, n. ${ }^{\circ}$ 3, fol. 3.

57 Idem.

58 Idem.

59 Ibidem, fols. 8-25.

60 Neste caso, trata-se do Cabildo que exercia, no mundo urbano da América hispânica, função muito semelhante à Câmara Municipal das cidades da América portuguesa.
} 
aplicar a justiça em casos de primeira instância ${ }^{61}$. Já os partidos rurais passaram a ser governados por capitães que estavam diretamente subordinados ao Capitão General de Cuba, evitando assim a participação do ayuntamiento no governo rural ${ }^{62}$.

Apesar dos grandes esforços e importantes resultados do Conde de Ricla -em sua busca pela Havana ordenada ${ }^{63}$-, as grandes transformações urbanísticas de Havana ocorreriam sob o governo do novo Capitão General de Cuba, nomeado em 1771. Felipe de Fondesviela y Ondeando, o Marquês de La Torre, herdou uma Havana extremamente militarizada e com uma atividade portuária em franco desenvolvimento. A paz que marcou os primeiros anos de seu mandato permitiu que o novo Capitão General fosse o primeiro a considerar o corpo conjunto da cidade de Havana durante a implementação de sua política de ordem pública ${ }^{64}$. Deste modo, segundo o próprio Marquês:

... entre los graves cuidados siempre procure sacar lugar para los asuntos pequeños: las horas en que habían de encender-se los hornos de las panaderías para excusar la incomodidad de que se quejaba el Vecindario; los parajes en que habían de arrojarse las heces que resultaban de la fábrica de aguardiente; el Riego de las Calles, para evitar el pollo y mitigar los ardores del Sol; me debieron providencias oportunas y repetidas ${ }^{65}$.

Não foram apenas os fornos das padarias de Havana que passaram a fazer parte do grande rol de responsabilidade do Capitão General. De La Torre recebeu uma cidade que dependia, em grande parte, do trabalho escravo. Por isso, questões miúdas sobre o escravismo, como a necessidade em comprar farinha de mandioca e banana para os escravos do rei que trabalhavam nas fortificações e demais construções da cidade, também fizeram parte da sua administração ${ }^{66}$. Menos do que se preocupar com o bem-estar dos cativos da Coroa, De La Torre precisava garantir que os africanos importados anos antes estivessem em condições que lhes permitissem executar os trabalhos que tinha em mente.

61 Ordenanzas para los Comissarios del Barrio, 1770, ANC, Sociedad Económica de Amigos del País.

62 Venegas Fornias, 2002: 43.

63 Rama, 1996.

64 Venegas Fornias, 1990: 12

65 Apuntes sobre las operaciones del capitán general de Cuba, 1777, AHN, Diversos-Colecciones, leg. 32, n. ${ }^{\circ} 23$.

66 Contrata de provisión de viandas para los forzados y negros del Rey, 1772, ANC, Intendencia General de Hacienda, leg. 540, n. ${ }^{\circ} 7$. 
Reconfiguração da Plaza de Armas, abertura da Alameda de Paula, a construção da Alameda de Extramuros (também conhecida como Alameda de Nuevo Prado) e do primeiro Teatro da cidade, e o investimento em obras de infraestrutura como o calçamento e a iluminação das ruas foram as principais obras que visavam a melhoria e o embelezamento da capital cubana e a ordenação dos partidos extramuros, cuja extensão acompanhava o crescimento da população de Havana. A administração do Marquês de La Torre inaugurou assim uma nova relação entre as duas porções da cidade, tornando a região extramuros mais arborizada agradável e melhor controlada.

Desde o governo do Conde Ricla, a população de Havana vinha aumentando gradativamente. Como a região intramuros não tinha como se expandir, partidos extramuros como San Lázaro, Jesus María e Guadalupe cresceram rapidamente, fazendo com que a demanda por água potável -antigo problema da cidade- aumentasse ainda mais. Frente tal crescimento, a Igreja construiu paróquias auxiliares e fundou cúrias rurais nas áreas interioranas, ficando a cargo dos juízes e capitães de partido evitar o crescimento da criminalidade nesses locais. Para conhecer e controlar o crescimento populacional, sob o comando do Marques de la Torre foi feito, em 1774, o primeiro censo de Cuba ${ }^{67}$.

Tabela 1. Censo populacional de Havana em 1774

\begin{tabular}{|l|r|r|r|r|r|}
\hline & \multicolumn{3}{|c|}{ Livres } & \multicolumn{2}{c|}{ Escravos } \\
\cline { 2 - 6 } & Brancos & Mulatos & Negros & Mulatos & Negros \\
\hline Homens & 26.331 & 3.082 & 2.029 & 685 & 13.242 \\
\hline Mulheres & 17.061 & 3.297 & 2.473 & 369 & 6985 \\
\hline & 6985 & 6.379 & 4.502 & 1.054 & 20.227 \\
\cline { 2 - 6 } Total Parcial & \multicolumn{3}{|c|}{54.273} & 21.281 \\
\hline Total & \multicolumn{5}{|c}{75554} \\
\hline
\end{tabular}

Fonte: Sagra, 1831: 3.

Os dados revelados pelo censo corroboram o lugar singular de Havana dentro de Cuba. O mesmo documento apontou que a população de Cuba era

67 Maria del Carmen Barcia assinalou que, em 1761, a população de Havana girava em torno de 37.000 habitantes, esse número duplicou em quinze anos. Cf. Barcia Zequeira, 2009b. 
de 171.620 habitantes, o que faz com que os habitantes de Havana representassem $44 \%$ do total da ilha. Dentre essas 75.554 almas, 35\% eram cativos, o que indica que grande parte das atividades de Havana continuava dependendo da mão-de-obra escrava para funcionar. Os documentos deste período sugerem que a maior parte dos escravos urbanos seguia trabalhando nas obras da Coroa, principalmente da construção e reparo de embarcações e no fabrico do tabaco.

O significativo crescimento demográfico de Cuba e, em especial de Havana, criou outras demandas. No longo relatório que fez para Carlos III assim que entregou seu posto em 1777, o Marquês de La Torre apontou sua preocupação com o crescente uso de guano ${ }^{68}$ nas edificações de toda a cidade. Além de facilitar possíveis incêndios (tendo em vista o alto poder de combustão desse material), o Capitão General apontou que tal prática acabava "impediendo la hermosura y ornato de la ciudad", o que lhe impeliu a publicar um Bando em 25 de junho de 1776, obrigando a substituição desse material em até dois anos.

Todavia, Havana não foi a única cidade a se beneficiar com a política do Marquês de la Torre. Seu governo foi marcado pela fundação de inúmeros pueblos e pela elevação de antigas povoações ao status de cidade, como o caso de Güines e Jaruco. Os princípios ilustrados que guiaram boa parte das reformas em Havana também foram aplicados nessas novas urbes, nas quais "se dispuso un plan para que con arreglo a él se delineasen la plaza y las calles con la extension y hermosuras convenientes ${ }^{69}$ ". Interessante notar que o próprio Capitão General vinculou a criação ou crescimento das cidades situadas na hinterland de Havana com a produção de gêneros agrícolas como o açúcar, o café (cujo primeiro plantio havia sido feito em 1768) e, sobretudo, o tabaco -produto que despertou interesses particulares do Marquês de la Torre $^{70}$.

68 Segundo o dicionário de Esteban Pichardo, guano era uma espécie de palma abundante em Cuba e que, antes da chegada dos espanhóis, já era utilizada em construções pelos grupos indígenas da ilha. Cf. Pichardo, 1861: 126-127.

69 Pichardo, 1861: 25.

70 Embora a comercialização do tabaco estivesse sob o monopólio da Real Companhia de Comercio de Havana desde 1740, a garantia que os produtores de tabaco tinham que sua produção seria comprada pela Coroa permitiu que o cultivo desse gênero fosse uma aposta certa para muitos colonos. Com o desenvolvimento das atividades portuárias e mercantis de Havana entre os anos de 1763 e 1774, inúmeras famílias criollas passaram a produzir esse gênero. O Marques de la Torre reservou diversas páginas de seus apontamentos para discorrer sobre a produção e, principalmente, a venda do tabaco, usando-o como exemplo positivo para o investimento na produção agrícola da ilha. Cf. Apuntes sobre las operacio- 
Embora fosse um burocrata peninsular, o Marquês de La Torre acabou se aproximando da oligarquia criolla e passou a apoiar abertamente o fomento da agricultura e do comércio na ilha, chegando inclusive a defender a maior importação de africanos escravizados para Cuba e a permissão para a venda interna de cativos (ladinos) por valores maiores do que aqueles que haviam sido pagos na compra dos recém-chegados ${ }^{71}$. Mas nem mesmo a intervenção direta do Capitão general mudou a política metropolitana no tocante à oferta de africanos escravizados para Cuba da década de 1770 .

É forçoso pontuar que junto com a falta de mão-de-obra, o crescimento da produção agrícola da hinterland de Havana enfrentava outro grande obstáculo: o Real Arsenal ou, mais especificamente, a Reserva das Florestas Reais. A importância que o estaleiro de Havana ganhou a partir dos anos de 1740 sempre foi digno de nota, sobretudo pelas autoridades espanholas. Como sublinhado por Funes, os esforços do Conde de Ricla tinham devolvido a dinamização dessa indústria que, entre os anos de 1765 e 1784, produziu 43 embarcações ${ }^{72}$. Além de contar com um número significativo de trabalhadores (a maior parte escravos), a produtividade invejável do Real Arsenal de Havana devia-se à proibição da derrubada por particulares de uma série de madeiras que estavam resguardadas pelo rei. As imediações de Havana eram compostas por florestas que possuíam grande diversidade de árvores, todas elas destinadas à produção e reparo das embarcações da Real Armada.

O limite imposto pelas reservas reais não se detinha à proibição do uso dessas madeiras para construção dos engenhos de açúcar. A floresta ocupava uma área que era extremamente cobiçada pela elite agrícola cubana. Além da proximidade com o porto e com a própria estrutura urbanística de Havana, os senhores de engenho também ambicionavam o solo fértil e virgem da região; a queimada de alguns hectares dessa floresta significaria terreno limpo e madeira abundante para o plantio e o processamento da cana de açúcar.

Aliado da futura sacarocracia cubana, Marques de La Torre entrou abertamente em conflito com Juan Bautista Bonet, Comandante da Marinha, que tinha poderes para restringir a exploração florestal em nome da construção naval ${ }^{73}$. Mas nem mesmo seu cargo de Capitão General de Cuba pesou durante tais embates. A conjuntura internacional continuava sendo favorável à

nes del capitán general de Cuba, 1777, AHN, Diversos-Colecciones, leg. 32, n. ${ }^{\circ} 23$, fols. 22-28.

71 Ibidem, fols. 29-30.

72 Funes Montes, 2008: 60.

73 Em 1767 foi estabelecido o cargo de Comandante Geral da Marinha do Porto de Havana, ilha de Cuba e Índias Ocidentais. Cf. Funes Montes, 2008: 60-61. 
produção das embarcações da Real Armada, o que acabava reforçando o papel de Havana como cidade-porto e estaleiro. Ainda que seu governo tenha recebido adjetivos louváveis, De La Torre não teve poder suficiente para transformar dois aspectos da economia cubana que estavam intimamente ligados: a dinamização da produção açucareira na hinterland de Havana e os usos dos africanos escravizados que chegavam à cidade, ainda que em pequeno número.

\section{O prelúdio de uma nova escravidão em Havana}

As autoridades hispânicas não fizeram ouvidos moucos aos argumentos do Capitão General de Cuba no tocante à ampliação do tráfico de escravos. A defesa do Marquês De La Torre endossava as inúmeras súplicas dos proprietários de Havana por mais braços escravos em Cuba, mercadoria essa que, desde a saída do Conde de Ricla, havia voltado a depender dos contrabandistas para chegar às casas e propriedades da elite criolla. Sendo assim, a Coroa espanhola decidiu atender aos pedidos de seus súditos insulares: ainda em 1773, foi permitido o desembarque direto de africanos escravizados em Cuba que, por não pararem mais no entreposto de Porto Rico, tiveram seus preços barateados. Cinco anos depois, em 1778, a própria Coroa decidiu assumir o incremento do tráfico de africanos escravizados, quando anexou as ilhas de Fernando Poo e Annobón (localizadas no Golfo da Guiné). Contudo, a pouca experiência nesse comércio e a precária estrutura dos comerciantes hispânicos manteve o tráfico de africanos escravizados nas mãos estrangeiras que, graças aos entraves coloniais, não conseguia suprir a demanda cubana ${ }^{74}$.

O tráfico de africanos escravizados acabou entrando na lógica caótica que passou a reger o comércio externo de Cuba, mais particularmente aquele realizado em Havana. A grande circulação de dinheiro na capital cubana aumentou ainda mais nos últimos anos da década de 1770, graças ao estreitamento das relações comerciais e políticas entre as autoridades espanholas da Flórida, Louisiania e Cuba com as colônias rebeldes da América britânica. Embora a guerra de Independência dos Estados Unidos tenha trazido preocupações constantes com a segurança da capital cubana, Havana acabou transformando-se no porto de escoamento de armas e munições que vinham da Espanha e da França para os colonos revoltosos da América do Norte. Com o aval de Carlos III, o comerciante Gardoqui efetuava o trânsito dessas mer-

74 Sobre a política escravista da Espanha a partir da década de 1770, ver: Murray, 1980: 6-9. Tornero Tinajero, 1996: 38-40. 
cadorias entre os portos de Havana e de New Orleans, o que rendeu muito dinheiro para a alfândega de $\mathrm{Cuba}^{75}$.

A intensa atividade portuária de Havana avançou pela década de 1780, quando a Coroa Espanhola decretou guerra contra a Inglaterra (1779-1783) tendo em vista que o rei Jorge III se recusava a restituir Gibraltar e Menorca para Carlos III, bem como rejeitava a ideia de sair de Honduras e das Flóridas. A estratégica posição geográfica em que estava localizada fez de Havana, uma vez mais, a base operacional para as tropas espanholas. Junto com a atividade portuária, gêneros básicos produzidos pelos havaneiros passaram a ser vendidos por preços altos. A abertura para o comércio com embarcações dos Estados Unidos (fossem ou não de guerra), foi mais uma fonte de renda para a alfândega e para os colonos de Havana, que -a despeito dos entraves internos- investiram boa parte do lucro arrecadado na compra ou melhoria de engenhos e demais propriedades agrícolas ${ }^{76}$.

Este investimento nas propriedades agrícolas acompanhou o incremento do tráfico impetrado pelas autoridades espanholas. Embora os traficantes hispânicos não tenham tido muito sucesso no transporte de africanos escravizados, comerciantes espanhóis serviram como testas de ferro para traficantes britânicos ${ }^{77}$, que desde 1779 tinham se tornado inimigos declarados da Espanha. Graças à essa estratégia, milhares de escravos adentraram os portos de Havana, e foram alocados nos engenhos que continuavam crescendo, e nas diferentes atividades da malha urbana da capital de Cuba. Observa-se então que a reforma ilustrada em Havana, aliada à conjuntura internacional da época, viabilizou a convivência de interesses econômicos que, embora distintos, estavam intimamente ligados. Nesse sentido, a década de 1780 foi um período chave na história da cidade.

Em 1787 -um ano depois da Coroa retomar o sistema de asiento- o intendente do Real Ejercito y Hacienda de Cuba, José Pablo Valiente, produziu um inventário dos esclavos del rey, a mando do monarca espanhol ${ }^{78}$. Neste documento (que está localizado no Arquivo Nacional de Cuba) foram listados 251 escravos, sendo 190 homens e 61 mulheres de acordo com o local em que trabalhavam. A lista, aparentemente simples, fornece o local de trabalho, o nome e a idade dos cativos; esse último item chamou atenção: a maior parte deles tinha mais que 40 anos e, como foram classificados como boçais (ou seja, de origem africana), é plausível que eles tenham entrado na ilha

\footnotetext{
75 Guerra y Sánchez, 1938: 181.

76 Ibidem: 183-185.

77 Cf. Tornero Tinajero, 1996: 40.

78 Sem título, ANC, Intendencia General de Hacienda, leg. 1036, n. ${ }^{\circ} 15$.
} 
décadas antes - provavelmente entre os governos do Conde de Ricla e do Marquês De La Torre.

A maior parte desses escravos trabalhava em áreas que estavam ligadas, direta ou indiretamente, à reordenação urbana e militar de Havana e às atividades inerentes a uma cidade-porto. Dentre as tarefas destinadas às transformações urbanísticas de Havana, setenta e cinco escravos estavam alocados na Canteira de San Lazaro, trabalhando com a extração de pedras utilizadas nas construções e calçamentos da cidade; quatro homens trabalhavam na extração de sal; três na Real Aduana (alfândega); oito cativos nos moinhos da cidade; seis escravos serviam as lojas de alimentos; e outros treze trabalhavam na Casa Blanca. Já os escravos destinados aos serviços militares estavam divididos da seguinte forma: três homens trabalhavam no Fuerte del Principe; doze cativos na Administração de la Brigada, três escravos eram ferreiros; e cinquenta e sete estavam alocados no Palenque de Artilleria (arena de Artilharia). Seis homens foram inventariados simplesmente como negros ingleses, contabilizando 190 esclavos del rey ${ }^{79}$.

Ainda que trate os escravos como negros bozales, a peça documental oferece poucos indícios sobre a procedência desses cativos. A maior parte deles foi descrita com nomes e sobrenomes de origem espanhola, com exceção de quatro escravos congos, dois mondongos, um mandinga e um carabalí. Ao que tudo indica, os africanos escravizados que possuíam alguma profissão tiveram suas atividades detalhadas, como no caso dos carpinteiros da Casa Blanca e os cativos destinados a buscar água.

Diferentemente do que ocorria com os negros bozales, a generalização da descrição dos serviços efetuados não se aplica aos escravos crioulos. Três cativos eram especializados na carpinteira de embarcações; dois eram armeiros; três foram descritos como jornaleiros; e ainda havia um ferreiro e um carpinteiro. Os cinco escravos crioulos mais jovens (que não haviam completado vinte anos) foram descritos como destinados a oficios, o que leva a crer que estavam em treinamento profissional ${ }^{80}$.

Segundo o inventário, as escravas executavam uma variedade menor de serviços. Trinta e nove negras bozaes eram as lavadeiras dos hospitais da cidade; e outras cinco foram classificadas como inúteis para serviços. Dentre as cativas crioulas, quatro estavam servindo particulares (com a anuência do Intendente) e onze lavavam roupa para fora. Embora pouco diversificadas, as atividades executadas pelas esclavas del rey estavam longe de ser menos estafantes. No ano seguinte ao levantamento do inventário, a cativa Sebastiana
79 Idem.
80 Idem. 
Josefa de 40 anos foi encaminhada ao campo para restabelecer sua saúde abalada de tanto lavar roupas hospitalares ${ }^{81}$.

Além de deixar as autoridades espanholas a par das atividades realizadas pelos seus escravos, o inventário descrito acima indica o intenso uso de cativos em diferentes serviços urbanos ligados ao Estado espanhol, inclusive nos serviços militares ${ }^{82}$. Outro exemplo disso consiste na solicitação feita pelo escravo José Aponte em 1784, situação em que o escravo (que fazia parte do Batalhão de Negros de Havana) pedia de Cádis, autorização para retornar a capital cubana a fim de obter sua liberdade ${ }^{83}$.

O que se observa a partir de 1780 é uma queda relativa do número de escravos urbanos, decréscimo que não acompanhava o ritmo, caótico, do tráfico transatlântico. Ainda que os ganhos de Havana entre os anos de 1774 e 1783 tenham sido expressivos, a Paz de Versalhes (que pôs fim a guerra entre espanhóis e ingleses) representou uma verdadeira crise para a economia da cidade $^{84}$. Com a atividade portuária normalizada, a única forma que os colonos tinham para manter o crescimento da economia cubana era por meio do investimento nas atividades agrícolas, principalmente de açúcar e tabaco. Neste contexto de crise, munido da autoridade e do respeito que o cargo de Intendente da Real Hacienda lhe outorgava, o criollo José Pablo Valiente se fez porta-voz dos interesses da oligarquia havaneira e, em 1788, tentou provar ao Consejo de Índias que a única maneira de gerar riqueza em Cuba seria suprimindo os obstáculos comerciais ${ }^{85}$. Ainda em 1788, vecinos de Havana organizaram outro documento em que defendiam os préstimos que a maior entrada de africanos escravizados traria para a colônia ${ }^{86}$. Se até então o número de escravos introduzidos na ilha havia permitido a reestruturação de Havana, ele ainda era insignificante para os anseios da oligarquia criolla que

81 Expediente n. ${ }^{\circ} 453$ firmado por el Sr. Intendente General, 1788, ANC, Intendencia General de Hacienda, leg. 970, n. ${ }^{\circ} 35$.

82 Jonhson, 1997.

83 Jose Aponte, 1784, Archivo General de Indias, Sevilla (AGI), Contrataciones, leg. 5527, n. ${ }^{\circ} 1$.

${ }^{84}$ Levi Marrero apontou que entre os anos de 1778 e 1782, Havana foi uma verdadeira base logística para o Império espanhol e, graças a tal posição, muito dinheiro circulou na cidade. Com o fim da guerra contra a Inglaterra e a assinatura do Tratado de Paris de 1783, uma grave crise assolou a economia espanhola e, consequentemente, a havaneira que além de sofrer uma aguda diminuição de suas atividades mercantis, também passou a ter mais um imposto cobrado pela arroba de açúcar. In.: Marreo, 1984: 7-8.

85 Guerra y Sánchez, 1906: 211. Piqueiras, 2006.

86 Sem título, 1789, AGI, Estado, leg. 16, n. ${ }^{\circ} 22$. 
almejava fazer de Cuba o que ingleses e franceses haviam feito de suas possessões antilhanas: colônias de plantation.

No dia 16 de dezembro de 1789, o bergantim estadunidense Bolcan, comandando pelo capitão Mr. Preston, aportou em Havana trazendo cento e cinquenta e nove africanos oriundos da costa da Guiné87. Três dias depois, outros 311 guinéus desembarcaram após a travessia atlântica na fragata inglesa Benjamin, capitaneada por Mr. Luico ${ }^{88}$. Num intervalo de três dias, 470 africanos escravizados entraram legalmente em Cuba sob a salvaguarda de duas bandeiras distintas. Esse número era praticamente o dobro da média anual da importação de escravos durante os primeiros duzentos e cinquenta anos do tráfico transatlântico para a ilha ${ }^{89}$.

O significativo número de escravos que adentrou o porto de Havana num intervalo de 72 horas era resultado direto da Real Cédula que concedia liberdade de três anos para o comércio de negros nas ilhas de Cuba, Santo Domingo, Porto Rico e nas províncias de Caracas ${ }^{90}$. Desde 28 de fevereiro de 1789, o rei Carlos IV havia temporariamente abolido o sistema de asiento, permitindo que o tráfico transatlântico fosse regido pelas leis do livre comércio. Tal medida, que podia ser entendida como a ratificação de uma prática já difundida, consentiu que diferentes nações passassem a vender africanos na ilha, e também viabilizou que a oferta e a procura ditassem o ritmo das negociações entre traficantes e futuros senhores de escravos. A repercussão entre a elite criolla foi tão positiva, que nos nove anos subsequentes à Real Cédula de 1789, outros onze pronunciamentos reais foram despachados pelo rei espanhol, todos eles expandindo o tráfico para a América ${ }^{91}$.

Mas a Real Cédula não veio sozinha. Em maio de 1789, o monarca espanhol também assinou outra peça em que determinava o "trato que debe darse a los esclavos" 92 . Em certa medida, as questões pontuadas por Carlos IV já haviam aparecido em documentos anteriores que pretendiam legislar a escravidão no mundo hispânico, como o Código negro carolino de $1785^{93}$. Instrução católica, alimentação adequada, incentivo ao matrimônio, limitação do número de castigos, e o reconhecimento da figura do síndico como inter-

87 Sem título, AGI, Santo Domingo, leg. 2207, documento n. ${ }^{\circ} 230$.

88 Ibidem, documento n. ${ }^{\circ} 232$.

89 Apoiado nas análises feitas por Aimes, Franklin Knight afirmou que entre os anos de 1521 e 1761 a média de escravos importados para Cuba girava em torno de 250 indivíduos por ano. Cf. Knight, 1970: 10.

90 Real cédula..., 1789.

91 Knight, 1970: 8.

92 Real Cédula..., 1789.

93 Howard, 1998: 3. 
mediário na relação entre senhores e escravos foram aspectos ressaltados no documento de 1789. Mas a Real Cédula também permitia a exploração desse escravo, que em épocas de colheita não poderia reclamar das 15 ou 16 horas de trabalho. É possível pontuar que as ordenações do monarca espanhol apelavam para o "bom censo" de senhores católicos, permitindo que, em meio à doutrina cristã, eles conseguissem obter o maior lucro possível sobre seus cativos, fossem eles urbanos ou rurais.

Conforme exposto, observa-se que a Guerra dos Sete Anos econfigurou as possessões do Novo Mundo, fazendo com que, a partir de 1763, Havana assumisse um lugar capital no contexto Atlântico espanhol. Estrategicamente localizada, a cidade transformou-se em porta de entra (e salvaguarda) da colônia que administrava. Não por acaso, em 1766 (três anos após a retomada de Havana pelos espanhóis), ao publicar uma obra sobre a história de Havana intitulada Llave del Nuevo Mundo. Antemural de las Indias Occidentales, Arrate y Acosta confessou que:

... el poco que me ha costado el título que le he puesto a este opúsculo; porque no es invención debida a mi voluntad y discurso, sino un glorioso epíteto con que ha querido la real grandeza distinguir y condecorar a La Habana, llamándola Llave del Nuevo Mundo ${ }^{94}$.

Segurança, organização e embelezamento eram as palavras de ordem do projeto ilustrado levado a cabo na capital cubana ${ }^{95}$. Justamente por isso, além dos ofícios e expedientes, planos e mapas foram ferramentas frequentemente utilizadas pelas autoridades locais. Era preciso conhecer e controlar as chaves do Atlântico espanhol. E para tanto, era fundamental ter braços escravos. Mas seria demais esperar que os usos desses escravos (africanos e crioulos) se resumisse apenas aos interesses e ao planejamento das reformas ilustradas implementadas na colônia. Dentro do processo de construção de uma Havana mais ordenada e segura, os usos da escravidão foram ganhando novos sentidos, sobretudo para a futura elite sacarocrata, que ansiava em tomar o lugar da Coroa espanhola e transformar-se na maior proprietária de escravos da ilha.

As atividades econômicas de Havana começaram então, a perder espaço para a produção agrícola, principalmente a açucareira, e os cativos urbanos eram insuficientes para levar a cabo o projeto de plantation da elite criolla. Graças às questões externas e aos investimentos e pressões dos havaneiros, "a ilha deixava de ser a cidade". A reforma ilustrada que devolvera à Havana

\footnotetext{
94 Arrate y Acosta, 1792: 2.

95 Rama, 1996.
} 
seu papel singular dentro do Império espanhol, também criou as condições para que o espaço urbano fosse, paulatinamente, perdendo sua pluralidade econômica em nome do açúcar. Era tempo de mudança e os ventos começavam a soprar para outras direções.

\section{BIBLIOGRAFÍA}

Aimes, H. A., History of Slavery in Cuba, 1511-1868, New York, G. P. Putnam's Sons, 1907.

Arrate y Acosta, José Martín Félix, Llave del Nuevo Mundo. Antemural de las Indias Occidentales, La Habana, Comisión Nacional Cubana de la UNESCO, 1964. Primeira publicação 1792 .

Barcia Zequeira, María del Carmen, "Negros en sus espacios: vida y trabajos en la Habana Colonial (espacios físicos, espacios sociales, espacios laborales)", José Antonio Pirqueiras (ed.), Trabajo libre y Coactivo en Sociedades de Plantación, Madrid, Siglo XXI, 2009a.

Barcia Zequeira, María del Carmen, Los ilustres Apellidos. Negros en la Habana Colonial, La Habana, Editorial de Ciencias Sociales, 2009b.

Belmonte Postigo, José Luis, "El impacto de la liberalización de la trata negrera en Santiago de Cuba, 1789-1794", Tiempos de América, 14 (Castellón, 2007): 35-47.

Belmonte Postigo, José Luis, “Brazos para el azúcar', esclavos para vender. Estrategias de comercialización en la trata negrera en Santiago de Cuba, 1789-1794", Revista de Indias, 249 (Madrid, 2010): 445-468.

Blackburn, R., A construção do escravismo no Novo Mundo. Do barroco ao moderno, 1492-1800, São Paulo, ed. Record, 2003.

Calleja Leal, Guillermo y O'Donnell Duque de Estrada, Hugo, 1762: La Habana inglesa: La toma de la Habana por los ingleses, Madrid, Agencia Española de Cooperación Internacional, Ediciones de Cultura Hispánica, 1999.

Casanovas, Joan, Bread, or Bullets. Urban Labor and Spanish Colonialism in Cuba, 1850-1898, Pittsburgh, University of Pittsburgh Press, 1998.

Davis, David Brion, O problema da escravidão na cultura ocidental, Rio de Janeiro, Civilização Brasileira, 2001.

De la Fuente, Alejandro, Havana and Atlantic in the Sixteenth Century, Chapel Hill, The University of North Carolina Press, 2008.

De la Fuente, Alejandro, "Esclavitud, 1510-1816", Consuelo Naranjo Orovio (coord.), Historia de Cuba, Madrid, CSIC/Ediciones Doce Calles, 2009: 129-151. 
Deschamps Chapeaux, Pedro y Pérez de La Riva, Juan, Contribución a la historia de la gente sin historia, La Habana, Editorial de Ciencias Sociales, 1974.

Díaz, María Elena, The Virgin, the king, and the royal slaves of El Cobre: negotiating freedom in colonial Cuba, 1670-1780, Stanford, Stanford University Press, 2012.

Elliot, J. H., Empires of the Atlantic World. Britain and Spain in America 1492-1830, New Heaven, Yale University Press, 2006.

Funes Montes, Reinaldo, From Rainforest to Cane Field in Cuba. An enviromental history since 1492, Chapel Hill, The University of North Caroline Press, 2008.

García del Pino, César, Toma de La Habana por los ingleses y sus antecedentes, La Habana, Editorial de Ciencias Sociales, 2002.

García, Gloria, La esclavitud desde la Esclavitud, La Habana, Editorial de Ciencias Sociales, 2003.

García Rodríguez, Mercedes, "El monto de la trata hacia Cuba en el siglo XVIII", Consuelo Naranjo Orovio y Tomás Mayo Gutiérrez (eds.), Cuba, la perla de las Antillas: Actas de las I jornadas sobre "Cuba y su historia", Madrid, Doce Calles, Consejo Superior de Investigaciones Científicas, 1994: 297-312.

García Rodríguez, Mercedes, Misticismo y capitales: La compañía de Jesús en la economía habanera del siglo XVII, La Habana, Editorial de Ciencias Sociales, 2000.

García Rodríguez, Mercedes, La aventura de fundar ingenios: La refacción azucarera en la Habana del siglo XVIII, La Habana, Editorial de Ciencias Sociales, 2004.

García Rodríguez, Mercedes, Los ingleses en el tráfico e introducción de esclavos en Cuba, 1715-1739, La Habana, Editorial de Ciencias Sociales, 2006.

García Rodríguez, Mercedes, Entre haciendas y plantaciones: Orígenes de la manufactura azucarera en la Habana, La Habana, Editorial de Ciencias Sociales, 2007.

González-Ripoll, María Dolores, "Organización político-administrativa y mecanismos del poder colonial, siglos XVI-XVIII", Consuelo Naranjo Orovio (coord.), Historia de Cuba, Madrid, CSIC, 2009: 253-272.

Guerra y Sánchez, R., Manual de Historia de Cuba (Economica, social y politica), La Habana, Habana Cultural S.A., 1938.

Howard, Philip A., Changing History. Afro-Cuban Cabildos and Societies of Color in the Nineteenth Century, Louisiania, Louisiania State University Press, 1998.

Jonhson, Sherry, "La Guerra Contra los Habitantes de los Arrabales: Changing Patterns of Land Use and Land Tenancy in and around Havana, 1763-1800", The Hispanic American Historical Review, 77/2 (Durham, May 1997): 181-209.

Jonhson, Sherry, The Social Transformation of Eighteenth-Century Cuba, Gainesvi1le, University Press of Florida, 2001. 
Knight, F., Slave Society in Cuba during the ninettenth century, Wisconsin, University of Wisconsin Press, 1970.

Knight, F. and Liss, P. (eds.), Atlantic Port Cities. Economy, Culture, and Society in the Atlantic World, 1650-1850, Knoxville, The University of Tenessee Press, 1991.

Kuethe, Allan J., Cuba, 1753-1815. Crown, Military, and Society, Knoxville, The University of Tennessee Press, 1986.

Kuethe, Allan J., "La desregulación comercial y la reforma imperial en la época de Carlos III: los casos de Nueva España y Cuba", Historia Mexicana XII/2 (México D.F., 1991): 265-292.

Kuethe, Allan J. y Andrien, Kenneth J., The Spanish Atlantic World in the Eighteenth Century: War and the Bourbon Reforms, 1713-1796, New York, Cambridge University Press, 2014.

Landers, Jane, Atlantic Creoles in the age of Revolutions, Cambridge, Harvard University Press, 2010.

Marrero, Levi, Cuba: economía y sociedad. Azúcar, ilustración y consciencia (17631868), vol. 10, Madrid, Editorial Playor, 1984.

Moreno, Fraginals, Cuba, Espanha, Cuba. Uma História Comum, Bauru, EDUSC, 1995.

Murray, David, Odius Commerce. Britain, Spain and the Abolition of the Cuban Slave Trade, Cambridge, Cambridge University Press, 1980.

Naranjo Orovio, C. y Santamaría García, A., La América Española, 1765-1898. Economía, Madrid, Editorial Síntesis, 2002. Colección Historia de España 3er milenio, núm. 20, dirigida por Elena Hernández Sandoica.

Ortega Pereyra, Ovidio, El Real Arsenal de La Habana, La Habana, Editorial Letras Cubanas, 1998.

Ortiz, Fernando, Cuban Counterpoint. Tobacco and Sugar, New York, Alfred A. Knopf ed., 1947. 1. a edição cubana de 1940.

Ortiz, Fernando, Los Negros Esclavos, La Habana, Editorial de Ciencias Sociales, 1987. Primeira edição 1916.

Perera, A. y Meriño, A., El cabildo carabalí viví de Santiago de Cuba: familia, cultura y sociedad (1797-1909), Santiago de Cuba, Editorial Oriente, 2013.

Pezuela, Jacobo de la, "Como vio Jacobo de la Pezuela la toma de la Habana por los ingleses: Cuatro capítulos de su historia de la isla de Cuba y un fragmento de su diccionario geográfico, estadístico, histórico de la isla de Cuba”, Emilio Roig de Leuschenring (ed.), Historia de la isla de Cuba y en especial de la Habana, Libro V, La Habana, Historiador de la Ciudad de la Habana, 1962: 22-23.

Pichardo, E., Diccionario provincial casi-razonado de Vozes Cubanas, La Habana, Imprenta del Gobierno, Capitanía General y Real Hacienda, 1861. 
Piqueras Arenas, J. A., La Habana colonial (visiones y mediciones, 1800-1877), Santa Cruz de Tenerife, Idea, 2006.

Placer Cervera, Gustavo, Los defensores del Morro, La Habana, Ediciones Union, 2003.

Placer Cervera, Gustavo, Inglaterra y La Habana: 1762, La Habana, Editorial de Ciencias Sociales, 2007.

Placer Cervera, Gustavo, El Ejercito y las milicias en la Cuba colonial 1763-1783, La Habana, Premio de la Academia de Cuba, 2009.

Portuondo Zúñiga, Olga, Santiago de Cuba desde su fundación hasta la Guerra de los Diez Años, Santiago de Cuba, Editorial Oriente, 1996.

Rama, A., The Lettered City, Durham, Duke University City, 1996.

Real cédula por la que Su Majestad concede libertad para el comercio de negros con las islas de Cuba, Sto. Domingo, Puerto Rico, y provincia de Caracas a los españoles y extranjeros, Madrid, Impr. Nacional, 1789.

Real Cédula del 31 de Mayo de 1789 sobre el trato que debe darse a los esclavos, Madrid, Impr. Nacional, 1789.

Roig de Leuchsering, Emilio, La Habana. Apuntes Históricos, tomo I, La Habana, Editora del Consejo Nacional de Cultura, 1963.

Sagra, Ramón. Historia economico-politica y estadística de la isla de Cuba, La Habana, Imprenta de las viudas Arazoza y Soler, 1831.

Santamaría García, Antonio y Vázquez Cienfuegos, Sigfrido, “Indios foráneos en Cuba a principios del siglo XIX: historia de un suceso en el contexto de la movilidad poblacional y la geostrategia del imperio español", Colonial Latin American Historical Review (Albuquerque, Winter 2013): 1-34.

Santos, Ynaê Lopes dos, Irmãs do Atlântico. Escravidão e espaço urbano no Rio de Janeiro e em Havana (1763-1844), São Paulo, USP, 2012.

Sanz Rozalén, Vicente, "Los negros del rey: Tabaco y esclavitud en Cuba a comienzos del siglo XIX", J. A. Piqueras Arenas (coord.), Trabajo libre y coactivo en sociedades de plantación, Madrid, Siglo XXI de España Editores, S.A., 2009: 151176.

Schneider, Elena, The occupation of Havana, War, trade and slavery in the Eighteenth-Century Cuba, Princeton, Princeton University, 2011.

Stein, Stanley J. and Stein, Barbara H., Silver, Trade and War. Spain and America in the Making of Early Modern Europe, Baltimore/London, The Johns Hopkins University Press, 2003.

Tornero Tinajero, Pablo, Crecimiento económico y transformaciones sociales, Madrid, Ministerio de Trabajo y Seguridad Social, 1996. 
Torres-Cuevas, Reyes, Esclavitud y Sociedad. Notas y documentos para la Historia de la Esclavitud negra en Cuba, La Habana, Editorial de Ciencias Sociales, 1986.

Valdés, Antonio J., "Como vio Antonio J. Valdés la toma de la Habana por los ingleses", Emilio Roig de Leuschenring (ed.), Historia de la Isla de Cuba y en especial de la Habana, Libro V, La Habana, Historiador de la Ciudad de la Habana, 1962: 55.

Varella, Claudia, Esclavos a sueldo. La coartación cubana en el siglo XIX, Castellón, UJI, 2010.

Venegas Fornias, Carlos, La urbanización de las murallas: dependencia y modernidad, La Habana, Editorial Letras Cubanas, 1990.

Venegas Fornias, Carlos, Cuba y sus pueblos. Censos y mapas de los siglos XVIII y $X I X$, La Habana, Centro de Investigación y Desarrollo de la Cultura Cubano Juan Marinello, 2002.

Fecha de recepción: 6 de junio de 2014.

Fecha de envío de las modificaciones: 3 de noviembre de 2014 .

Fecha de aceptación: 14 de enero de 2015.

\section{La Habana Borbónica. \\ La reforma ilustrada y la esclavitud en La Habana (1763-1790)}

La eminencia del Tratado de París (1763) puso fin a una serie de cambios en la configuración del Atlántico mundial. La Guerra de los Siete Años había anunciado el protagonismo de las nuevas potencias del viejo continente, advirtiendo de la fragilidad de los dibujos de las posesiones europeas en América. Las transformaciones urbanas guiadas por los principios ilustrados eran herramientas usadas por la Corona española, mientras que la élite criolla de Cuba anhelaba más esclavos. El propósito de este artículo es analizar cómo fueron orquestados las reformas borbónicas y el aumento de la esclavitud urbana en La Habana entre los años de 1763 y 1790.

Palabras Clave: La Habana; reforma ilustrada; esclavitud; espacio urbano; 1763-1790. 


\section{Bourbon Havana. \\ Enlightenment Reform and Slavery in Havana (1763-1790)}

The significance of the Treaty of Paris (1763) put an end to a series of changes in the Atlantic World setting. The Seven Years' War had proclaimed the predominance of new powers on the Old Continent, issuing a warning about the vulnerability of European possessions drawn up in America. Urban transformations guided by Enlightenment principles were the tools used by the Spanish Crown, while Cuba's Creole elite craved more slaves. The purpose of this article is to analyse how Bourbon reforms and increased urban slavery were orchestrated in Havana between 1763 and 1790.

KEY WORDS: Havana; enlightenment reform; slavery; urban space; 1763-1790. 